\title{
The Libyan NTC Law No.38 2012: A Disguised Amnesty
}

\author{
HAMED HASHEMI SOUGHEH \\ ROHAIDA NORDIN
}

\begin{abstract}
The armed conflict of Libya occurred in 2011 and the authoritarian government of Ghaddafi felt down. During the conflict serious violations of human rights and humanitarian rights law (IHL) occurred and both sides committed serious crimes included of willfull killings, rape, looting, torture and aarbitrary arrests. After the fall of Ghoddafi, a transitional government came to power in Libya that was known as the National Transitional Government of Libya (NTC). The Libyan NTC adopted amnesty laws and considered it as part of the transition of power from the previous government to the new one. This amnesty law was criticized by human rights organizations and human rights activists. In this article after providing a brief introduction to amnesty and introducing various types of it and contemplating on transitional justice, the NTC amnesty law will be examined.
\end{abstract}

Keywords: Libyan conflict, amnesty, transitional government, human rights, humanitarian laws

\section{INTRODUCTION}

After the fall of any authoritarian regime, the leader, elites and military forces who committed serious crimes such as torture, willful killings and looting should be punished. Sometimes, there are situations where the troops of the previous government will not give up on fear of retribution and continue to fight. In fact, fear of punishment is a serious impetus for continued insurgency and military killings. ${ }^{1}$ In such a situation, amnesty can be a solution to lasting peace. The problem is that, providing amnesty to law violators is against justice and the family of the victims will mostly fell unhappy with the amnesty laws. In other words, there is a conflict between amnesty and transitional justice. ${ }^{2}$

Against the abovesaid background, this manuscript examines the conflict between amnesty and traditional justice in the case of the Libyan amnesty law, the Libyan NTC Law No. 38. After the fall of Ghoddafi, a transitional government came to power in Libya that was known as the National Transitional Government of Libya (NTC). The Libyan NTC adopted NTC Law No. 38 as an amnesty law and considered it as part of the transition of power from the previous government to the new one. During the armed conflict in 2011, serious violations of human rights and humanitarian laws occurred and both sides of the armed conflict committed serious crimes included of willfull killing, rape, looting, torture and aarbitrary arrests. Under the Libyan amnesty law, these criminals may escape justice. Using qualitative and critical approach, this manuscript examine the relevant primary and secondary sources to provide an analysis on the concepts of transitional justice and amnesty under international law before critically examine the legitimacy of the Libyan amnesty law.

\section{TRANSITIONAL JUSTICE}

Transitional justice means judicial and nonjudicial measures aimed at remedying human rights violations. ${ }^{3}$ Measures taken by transitional justice include prosecution of the law violators, fact finding commission and various types of compensation. Transitional justice is crucial because it creates social security and trust. The more bloody a government falls, the less likely it is that a democratic government come to 
power. Put differently, transitional justice increase the smooth shifting of power and increases the likelihood of formation of a democratic government.

Transitional justice is not necessarily about criminal prosecutions but also preventive measures and root finding procedures. Ian Bremmer in his book entitles as "The J Curve" writes, the movement of an authoritarian government from the left side of the curve to the right side, heavily depends on the adopted policies by the transitional forces and many other factors. On the left side of the Bremmer $\mathrm{J}$ Curve, there are stable authoritarian governments and on the right side, there are stable democracies. Any State during its process from the left side of the $\mathbf{J}$ Curve i.e. authoritarian regime to the right side i.e. formation of a democratic government, should tolerate internal unrests and chaotic situations. There is no guarantee that suffering an internal chaos will be able to form a democratic government after the chaos. One of the factors that may drive the table from left to the right is transitional justice. 4

The aim of transitional justice is protecting and promoting human rights. However, under the principle of transitional justice, law violators among governmental and military personnel sometimes are dismissed and sometimes are given a second chance. Transitional justice is also seen as a vehicle in providing amnesty to human rights abusers or law violators. Providing amnesty to law violators is against the rule of law and perpetuates human rights abuses in the new government.

\section{CONCEPT OF AMNESTY}

Various types of amnesty were recognised given the fact that the scope and process for amnesty depended closely on the circumstances of the State and the relevant peace negotiations. Each amnesty process may have a positive or negative effect on democratization of the respective State. According to the Office of the High Commissioner of Human Rights (OHCHR), amnesty includes legal measures that prevent the commencement of any criminal prosecution against certain groups or individuals or that will nullify previous legal liabilities. ${ }^{5}$ Different types of amnesties are as follows:

i. If violators of human rights adopt amnesty laws to protect themselves from liability, that is called "selfamnesty";

ii. If amnesty laws are not adopted by law violators, but groups and individuals that violated international human rights law (IHRL) and international humanitarian law (IHL) are exempted from liability or victims are deprived of the opportunity to provide the facts on the violations, that is called "blanket amnesty";

iii. If the law violators are exempted from prosecution on condition that they coordinate and provide information and facts to disclose the committed violations, that is known as "conditional amnesty"; 6

iv. If the laws and measures of a State are adopted is such a way that they block any prosecution for the perpetrated crimes without any explicit refrence to "amnesty", that is "de facto amnesty"; 7

v. If the amnesty law is perfect but the authorities interpret it in such a way that it is inconsistent with the IHRL obligations of the State, that is known as "disguised amnesty.",

Argentina in 1983 adopted a selfamnesty law, according to which all the 
penal actions related to unlawful acts committed for the purpose of preventing or put an end to terrorist activities between 1973 and 1982 is discontinued. ${ }^{9}$ Thus, the relevant law violators escaped sanctions or punishments for their actions. As one may notice, self-amnesty is adopted unilaterally by governments who have committed international crimes and violated human rights in large scales. This type of amnesty is regarded illegal and illegitimate. ${ }^{10}$ Selfamnesties in the inter-American system is considered violation of the American Convention of Human Rights 1969. ${ }^{11}$

The best example for blanket amnesty is amnesty law adopted on May 7, 2009 by Joseph Kabila of the Democratic Republic of Congo. According to International Centre for Transitional Justice (ICTJ), this law is rewarding the violence and scoring the crime perpetrators thus, granting large blanket amnesty is unacceptable. $^{12}$ Blanket amnesty creates temporary peace but in long run causes a more wide scale bloodshell. If amnesty is provided in large scale and includes many people, it is a kind of bonus for law violators and those who have resorted to violence. Arguably, this type of amnesty is rewarding the violence. In other words the scope of amnesty should be as little as possible and never excludes international crimes. Adopting blanket amnesty prevents the discovery of truth and holds off confession for commiting wrongdoing by perpetrators. ${ }^{13}$ This is because, to certain extend pleading guilty itself is a form of punishment.

An example of conditional amnesty is the amnesty adopted by the South African Truth and Reconciliation Commission (TRC). According to the Promotion of National Unity and Reconciliation Act of 1995, specific conditions such as personal attendance of the amnesty seeker, details of the committed acts and existence of political motivation should be met before granting amnesty. ${ }^{14}$ The problem with this amnesty law was that, every applicants could easily tailor his/her story to meet the conditions and were hardly verified.

Human rights organizations normally objected to providing amnesty to law violators and they try to take measures to prosecute and punish violators of human rights. Human rights advocates believe that amnesty is not a good solution for dealing with human rights vilators. ${ }^{15}$ In African States, the insurgents condition their participation in peace gentitiations and disarmament to amnesty.

Under the IHRL, it is impossible to provide amnesty for war crimes, genocide, crimes against humanity or in such a way as to deprive victims of effective remedies or ban any investigation into the crimes. ${ }^{16}$ It is a fact that some crimes such as war crimes, crimes against humanity, wilful killing, torture and enforced disappearance are not forgivable. ${ }^{17}$ One may trace the source of the prohibition against the granting of amnesty for serious crimes and violations of IHL and IHRL, namely the Security Council Resolution No. 955 and Article 1 of the Statute of the International Criminal Tribunal for the Former Yugoslavia (ICTY). The preamble of the Rome Statute of the International Criminal Court (ICC) 1998 also reiterates the termination of the practice of providing impunity to those who have committed the most serious crimes. The American Commission of Human Rights announced the issue of the public amnesty granted by the government of El Salvador as a violation of Article 3 of the Geneva Conventions 1949 and Additional Protocol II $1977 .^{18}$

However, on the other hand Paragraph 5 of Article 6 of the Additional Protocol II to the Geneva Conventions of 1949 obligates parties to grant amnesty during internal armed conflicts, either 
through legislation or agreements between the parties to the armed conflict. Paragraph 5 provides: At the end of hostilities, the authorities in power shall endeavour to grant the broadest possible amnesty to persons who have participated in the armed conflict, or those deprived of their liberty for reasons related to the armed conflict, whether they are interned or detained. The Security Council $^{19}$ and the General Assembly ${ }^{20}$ of the United Nations (UN), the European Union (EU) and North Atlantic Treaty Organisation (NATO) have also made recommendations on the granting of amnesty after the end of armed conflicts. Moreover, according to the customary IHL, after hostilities, the parties to an armed conflict should do their best to grant amnesty to individual perpetrators in the internal war. $^{21}$

In conclusion, amnesty is not just a legal debate but also a political one. In some instances amnesty leads to a stable peace and sometimes creates a barrier to peace. Providing wide scale of amnesty may cause a sense of injustice and increases the sense of revenge. Amnesty is not forgiving the wrongdoer because, the amnesty grantor is not qualified to grant forgiveness and it is only the victim that can forgive the perpetraror. Amnesty also means that compensation should not be criminal. Ideally, amnesty should be provided in a democratic process and it should be provided in a situation that a democratic government is coming to power. If an authotarian regime comes to power and provides amnesty for its own forces, this amnesty lacks legitimacy. Moreoever, amnesty should not cause the crime remains uncompensated; it can also have administrative and civil aspects.

\section{LEGITIMACY OF AMNESTY UNDER LIBYAN NTC LAW NO 38}

The Libyan NTC granted amnesty through a legislation, but the problem was that it granted amnesty on certain conditions, to those who had committed crimes. ${ }^{22}$ Such an act is in violation of the obligation to investigate and prosecute. Ideally, the granting of amnesty to members of armed groups in an internal armed conflict paves the way towards the peace and stability of the country. Armed groups lay down their weapons if they are sure that after the peace agreement(s), they will be immune from prosecution. In this situation, the de facto government is in a dilemma because, on the one hand, granting amnesty to those who perpetrated crimes during an armed conflict is in violation of IHRL and IHL, ${ }^{23}$ as the IHL and IHRL instruments request that State Parties ensure that violators are punished through the establishment of appropriate criminal proceedings. ${ }^{24}$ On the other hand, if it refrains from granting amnesty to the members of the armed group, there will be no lasting peace. It should be noted that there is no contradiction between providing reparation to the victims of crimes and providing amnesty so that the combatants put down their arms and submit to official forces i.e. the army and the police.

On 2nd May 2012, the Libyan NTC passed Law No. 38 which provides that there should be no penalty on the military personnel of civil actions committed during the internal armed conflict of Libya by revolutionaries "with the goal of promoting the revolution." 25 Literally, this meant that those revolutionaries who committed serious crimes could walk away free. Ironically, the amnesty law provides immunity for those who committed crimes against humanity and war crimes but did not establish any factfinding process. The passing of Law No. 38 also been seen as an indicator that members 
both sides of the Libyan internal armed conflict had committed violations of IHL and IHRL or else there would have been no need for amnesty. ${ }^{26}$

Moreover, according to an organisation, Lawyers for Justice in Libya (LFJL), Law No. 38 contradicts the NTC Declaration issued on 3 August 2011 that is the source of its legitimacy. The wording of Law No. 38 is vague and may lead to arbitrary detention. ${ }^{27}$ Human Rights Watch calls Law No. 38 the "victor's justice.", 28 The CILa criticized the amnesty law by saying that although Law No. 38 mentions on the possibility of reconciliation between the criminals and the victims, in reality the granting of amnesty may prevent the victims from getting compensation. ${ }^{29}$ It is also urged for the NTC in making sure that the process of amnesty is done according to international law and that all those who committed serious crimes during the armed conflict were held accountable. ${ }^{30}$ Finally, it should be emphasised that Heller categorized Law No. 38 as a blanket amnesty. ${ }^{31}$ Despite of its legal implication in the domestic context, Law No. 38 however did not prevent international courts such as the ICC from prosecuting perpetrators for serious violations of IHRL during the armed conflict of Libya.

\section{CONCLUSION}

The Libyan NTC passed Law No. 38 and provided amnesty to those who committed war crimes, and the regulations were so vague as to lead to arbitrary detentions. The attitude of the NTC towards those who committed war crimes during the internal armed conflict of 2011 was discriminative; it provided amnesty for the thuwar but, on the other hand, deprived the Gaddafi loyalists of some of their fundamental rights, such as visits by their family while in custody. Saif al Islam was specifically arrested arbitrarily and was also deprived of family visits. The type of the amnesty provided by the Libyan NTC was "self-amnesty" arguably can also be categorised as "disguised amnesty." It is suggested for the Libyan authorities to adopt transitional justice prodeedures and render the IHRL and IHL violaters for adjudication before the international courts, tribunals or hybrid courts.

\section{NOTES}

1. A. J. Olusegun, Nigeria Prisons and the Dispensation of Justice', (2012) 3 AFRREV LJAH, p. 211.

2. K McEvoy \& L Mllinder, 'Amnesties in Transition: Punishment, Resotoration, and the Govenrnace of Mercy', (2012) 3 (39) Journal of Law and Scoiety, P0 410.

3. M. Krotoszynski, 'The Transitional Jutcie Models and the Justification of Means of Dealing with the Past', (2016) 6 (3) Onati Socio-legal Series, PP587-588.

4. S. Chesterman, 'Rough Justice: Establishing the Rule of Law in Post-Conflcit Territories', (2005) 20 (1) Ohio State Journal of Dispute Resolution, P75.

5 Office of the High Commissioner for Human Rights, 'Rule of Law Tools for Post Conflict States', 2009, United Nations, New York and Geneva, P5.

6 ICTJ, 'Navigating Amnesty and Reconciliation in Nepal's Truth and Reconciliation Commission Bill', (2011) The International Centre for Transitional Justice, P1.

7 D. K. Pokhrel, 'Nuances of the de facto Amnesty: A Case of Nepal', (2013) Human Rights thesis, Central European University.

8 K. Haas, 'Truth, Trials, Transition: The Meaning of Justice in Post-Dirty Argentina', (2012) Senior Essay, History Department, Yale University, P 33. History.yale.edu/sites/default/files/Haas Katherine senior essay 2012.pdf accessed [8 May 2015].

9. C. A. E. Bakker, 'A Full Stop to Amnesty in Argentina: The Simon Case', (2005) 3 (5) Journal of International Criminal Justice, P1106.

10. C. Collins, 'Prosecuting Pinochet: Late Accountability in Chie amd the Rule of the Pinoche case', (2009) 5 Human Rights, Global Justice and Democracy, P 10.

11. J. Contesse, 'The Final Word? Constitutional Dialogue and the Inter-American Court of Human 
Rights”, (2017) 15 (2) International Journal of Constitutional Law, P423.

12. International Center for Transitional Justice, 'Amnesty Must Not Equal Impunity', [2009] ICTJ, P1.

13. Y. Naqvi, 'The Right to Truth in International Law: Fact or Fiction", (2006) 88 (826) International Review of the Red Cross, P 249.

${ }^{14}$. C. Jenkins, 'They Have Built a Legal System Without Punishment: Reflections on the Use of Amnesty in the South African Transition', (2007) 64 Transformation, P 39.

15. S. Vandeginste, "Bypassing the Prohibition of Amnesty For Human Rights Crimes under International Law: Lessons Learned from the Burundi Peace Process', (2011) 29 (2) Netherlands Quarterly of Human rights, PP 190192.

16 See, for example, Special Court for Sierra Leone, Prosecutor v. Brima Bazzy Kamara, Case No. SCSL -2004-16-AR72 (E), Appeals Chamber, Decision on Challenge to Jurisdiction: Lome Accord Amnesty, Para. 73.

17 UN Security Council Resolution 1120 (1997), Resolution 1315 [2000] S/RES/1315.

18 Inter-American Commission on Human Rights, Organization of American States (OAS), Case 10.480, cidh.org > accessed [23 May 2014].

19 UN Security Council Resolutions 191 [1964] S/RES/191; Resolution 473 [1980] S/RES/473, Resolution 1055 [1996] S/RES/1055; Resolution 1120 [1997] S/RES/1120.

20 UN General Assembly Resolution 47/141 [1993] A/RES/47/141; Resolution 49/207 [1995] A/RES/49/207; Resolution 53/164 [1999] A/RES/53/164.

21 P. Salem \& A. Kadlec, 'Libya's troubled transition', P611.

22 Report of the Commission of Inquiry on Libya, [2011] A/HRC/17/44, P810.

23 UN Human Rights Committee, General Comment No. 20; ICCPR Art. 7.

24 W. S. Dodge, 'Breaking the Public Law Taboo', (2002) 43 Harvard International Law Journal, P161.

25 Report of Human Rights Watch, 11 May 2012, www.hrw.org/news/2012/05/11/libya-amendspecial-new-procedures-law > [12 June 2014].

26 M. Kersten, impunity rules: Libya passes controversial amnesty law, 2012, http://justiceinconflict.org/2012/05/08/impunity- rules-libya-passes-contraversial-amnesty-law. Accessed [3 May 2012].

27. Lawyers for Justice in Libya, LFJL Strongly Condemns New Laws Breaching Human Rights and Undermining the Rule of Law. www.libyanjustice.org/news/news/post/23-lfjlstrongly-condemns-new-laws-breaching-humanrights-and-undermining-the-rule-of-law accessed [3 May 2015].

28 L. Moreno-Ocampo, Libya: Letter to the ICC Prosecutor on Libyan Amnesty Laws, 2012, Human Rights Watch. www.hrw.org/news/2012/ 05/25/libya-letter-icc-prosecutor-libyan-amnestylaws. Accessed [3 May 2015].

29 CILa, Paragraph 109.

30 CILa, Paragraph 137.

31 K. J. Heller, 'Surprise, the NTC Amnesties its Own Crimes', 2012, Opinio Juris. Opiniojuris.org/2012/05/09/surprise-the-ntcamnesties-its-own-crimes. Accessed [8 May 2015].

\section{REFERENCES}

Bakker, C. A. E. 2005. A full stop to amnesty in Argentina: The Simon Case. Journal of International Criminal Justice 3(5).

Chesterman, S. 2005. Rough justice: Establishing the rule of law in postconflcit territories. Ohio State Journal of Dispute Resolution 20 (1).

Collins, C. 2009. Prosecuting Pinochet: Late accountability in Chie amd the rule of the Pinoche case. Human Rights, Global Justice and Democracy 5.

Contesse, J. 2017. The final word? Constitutional dialogue and the InterAmerican Court of Human Rights. International Journal of Constitutional Law 15 (2).

Dodge, W. S. 2002. Breaking the public law taboo. Harvard International Law Journal 43.

Haas, K. 2012. 'Truth, Trials, Transition: The Meaning of Justice in Post-Dirty Argentina', Senior Essay, History 
Department, Yale University, P 33. History.yale.edu/sites/default/files/H aas Katherine senior essay 2012.pdf accessed [8 May 2015].

Heller, K. J. 2012. Surprise, the NTC amnesties its own crimes. Opinio Juris. Opiniojuris.org/2012/05/09/sur prise-the-ntc-amnesties-its-owncrime s. Accessed [8 May 2015].

ICTJ. 2011. Navigating amnesty and reconciliation in Nepal's truth and reconciliation Commission Bill. The International Centre for Transitional Justice.

Inter-American Commission on Human Rights, Organization of American States (OAS), Case 10.480, cidh.org $>$ accessed [23 May 2014].

International Centre for Transitional Justice. 2009. 'Amnesty Must Not Equal Impunity',. ICTJ.

Jenkins, C. 2007. They have built a legal system without punishment: Reflections on the use of amnesty in the South African transition. Transformation 64.

Krotoszynski, M. 2016. The transitional jutcie models and the justification of means of dealing with the past. Onati Socio-legal Series 6 (3).

Kersten, M. 2012. impunity rules: Libya passes controversial amnesty law, http://justiceinconflict.org/2012/05/0 8/impunity-rules-libya-passescontraversial-amnesty-law. Accessed [3 May 2012].

Lawyers for Justice in Libya, LFJL Strongly Condemns New Laws Breaching Human Rights and Undermining the Rule of Law. www.libyanjustice .org/news/news/post/23-lfjl-stronglycondemns-new-laws-breachinghuman-rights-and-undermining-therule-of-law accessed [3 May 2015].
McEvoy, K. \& Mllinder, L. 2012. 'Amnesties in transition: Punishment, resotoration, and the govenrnace of mercy' Journal of Law and Scoiety 3 (39).

Moreno-Ocampo, L. 2012. Libya: Letter to the ICC Prosecutor on Libyan Amnesty Laws, Human Rights Watch.

www.hrw.org/news/2012/05/25/libya -letter-icc-prosecutor-libyanamnesty-laws. Accessed [3 May 2015].

Naqvi, Y. 2006. The right to truth in international law: Fact or fiction. International Review of the Red Cross 88 (826): 192.

Office of the High Commissioner for Human Rights, 2009. 'Rule of Law Tools for Post Conflict States', United Nations, New York and Geneva.

Olusegun, A. J. 2012. Nigeria prisons and the dispensation of justice. AFRREV LJAH 3.

Pokhrel, D. K. 2013. Nuances of the de facto Amnesty: A Case of Nepal. Human Rights thesis. Central European University.

Salem, P. \& Kadlec, A. 2012. Libya`s troubled transition. Carnegie Endowment for International Peace (Jun. 1, 2012) https://www.jstor.org/stable/resrep12 908.

Report of the Commission of Inquiry on Libya, 2011. A/HRC/17/44.

Report of Human Rights Watch, 11 May 2012 , www.hrw.org/news/2012/05/11/liby a-amend-special-new-procedureslaw > [12 June 2014].

Special Court for Sierra Leone, Prosecutor v. Brima Bazzy Kamara, Case No. SCSL -2004-16-AR72 (E), Appeals 
Chamber, Decision on Challenge to Jurisdiction: Lome Accord Amnesty.

UN Security Council Resolution 1120. 1997. Resolution 1315 [2000] S/RES/1315.

UN Security Council Resolutions 191 [1964] S/RES/191; Resolution 473 [1980] S/RES/473, Resolution 1055 [1996] S/RES/1055; Resolution 1120 [1997] S/RES/1120.

UN General Assembly Resolution 47/141. 1993. A/RES/47/141; Resolution 49/207 [1995] A/RES/49/207; Resolution $\quad 53 / 164 . \quad 1999$. A/RES/53/164.

UN Human Rights Committee, General Comment No. 20; ICCPR Art. 7.

Vandeginste, S. 2011. Bypassing the prohibition of amnesty for human rights crimes under international law: Lessons learned from the burundi peace process. Netherlands Quarterly of Human Rights 29(2)0.-

Hamed Hashemi Sougheh

Faculty of Law Universiti Kebangsaan Malaysia 436000 UKM Bangi, Selangor

Associate Professor Dr. Rohaida Nordin

Faculty of Law

Universiti Kebangsaan Malaysia

436000 UKM Bangi, Selangor

Email: rohaidanordin@ukm.edu.my 